IRA-International Journal of Education \&

Multidisciplinary Studies

QUARTERLY

ISSN 2455-2526; Vol.16, Issue 04 (Oct.-Dec., 2020)

Pg. no. 259-267.

Institute of Research Advances

https://research-advances.org/index.php/IJEMS

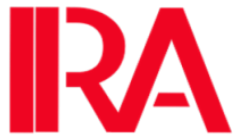

\title{
Review of Empirical Research into Teachers' Belief related to Intercultural LanguageTeaching
}

Peng Zilian ${ }^{1}$

School of Foreign Foreign Studies, Yangtze University, Hubei, 434023 P.R. China.

Type of Work: Peer-Reviewed

DOl: http://dx.doi.org/10.21013/jems.v16.n4.p8

\section{How to cite this paper:}

Zilian, P. (2020). Review of Empirical Research into Teachers' Belief related to Intercultural LanguageTeaching. IRA International Journal of Education and Multidisciplinary Studies (ISSN 2455-2526), 16(4), 259-267. DOl: http://dx.doi.org/10.21013/jems.v16.n4.p8

(C) Institute of Research Advances.

This work is licensed under a Creative Commons Attribution-NonCommercial 4.0 International License subject to a proper citation to the publication source of the work.

Disclaimer: The scholarly papers as reviewed and published by the Institute of Research Advances (IRA) are the views and opinions of their respective authors and are not the views or opinions of the IRA. The IRA disclaims of any harm or loss caused due to the published content to any party.

Institute of Research Advances is an institutional publisher member of Publishers International Linking Association Inc. (PILA-CrossRef), USA. The institute is an institutional signatory to the Budapest Open Access Initiative, Hungary advocating the open-access of scientific and scholarly knowledge. The Institute is a registered content provider under Open Access Initiative Protocol for Metadata Harvesting (OAI-PMH).

The journal is indexed \& included in WorldCat Discovery Service (USA), CrossRef Metadata Search (USA), WorldCat (USA), OCLC (USA), Open J-Gate (India), EZB (Germany) Scilit (Switzerland), Airiti (China), Bielefeld Academic Search Engine (BASE) of Bielefeld University, Germany, PKP Index of Simon Fraser University, Canada.

${ }^{1}$ Peng Zilian is a postgraduate of QX191 in the School of Foreign Studies, Yangtze University. 
IRA-International Journal of Education \& Multidisciplinary Studies

ABSTRACT

In recent years the topic of intercultural language teaching has attracted considerable research interest, few in the form of empirical studies of teachers' belief related to intercultural language teaching. Arguing the need to make a clear direction for further research of this kind, this paper intends to review the common issues investigated in these studies, and the similarities or differences between their findings. The review found the research focus of these studies can be mainly divided into six categories: teachers' teaching objectives of language teaching and culture teaching; language teachers'distribution of teaching time; the content and the way of language teachers culture teaching; language teachers' belief on ICC and ILT; students'attitudes towards ILT; and the degree of teachers familiarity with foreign culture. Apart from language teachers' distribution of teaching time, the way of language teachers' cultural teaching and language teachers' belief on ICC, the findings of other aspects vary among different studies, even in the same study. In light of these findings, factors affecting the above differences and areas for further research are suggested.

Keywords: Review; intercultural communicative competence; intercultural language teaching; teachers' belief

\section{Introduction}

Although definitions of teachers' beliefs vary, the term is generally used to refer to evaluative propositions that teachers hold consciously or unconsciously and which they accept as true while recognizing that other teachers may hold alternative beliefs on the same issue (Borg, 2001).

The notion of 'intercultural communicative competence (hereafter ICC) originated in the work of Byram (1997) and Byram and Zarate (1997). Byram (1997) proposes a model of ICC involving three components: attitudes, knowledge, and skills (of two kinds).

An approach to intercultural language teaching (hereafter ILT) was developed by Byram (1997), addressing the integration of language and culture in language teaching. ILTis promoted in many educational systems. Nevertheless, as shown comprehensively in Sercu et al. (2005), and other studies in China (e.g. Zhang, 2007; Cheng, 2012; Chen, 2013; Han, 2014) and abroad (e.g. Conway et al., 2010; Young \& Sachdev, 2011), ILT is not commonly practiced, even if teachers are favorably disposed towards it.

The main works identified for the review included 7 journal articles (Castro et al., 2004; Atay et al., 2009; Cheng, 2012; Han, 2014; Kissau et al., 2014; Czura, 2016; Oranje \& Smith, 2018), a book (Sercu et al., 2005) and a dissertation (Chen, 2013) which were all empirical research into teachers' belief related to ILT that can be found at home and abroad. This review intends to answer these two questions:

1. What are the common issues that have been investigated in these studies?

2. Are there any similarities or differences between their findings?

\section{The review}

In order to find out the common issues investigated in these studies, the author first sorted out the research questions of each study and then categorized the similar research questions together. The research 
IRA-International Journal of Education $\Xi^{0}$ Multidisciplinary Studies

questions of those studies can be mainly divided into six categories: to investigate (1) teachers' teaching objectives of language teaching and culture teaching; (2) language teachers' distribution of teaching time; (3)the content and the way of language teachers culture teaching; (4) language teachers' belief on ICC and ILT; (5)students' attitudes towards ILT; (6)the degree of teachers familiarity with foreign culture. The findings of each research were presented subsequently based on these categories of research questions.

\subsection{Teachers' teaching objectives of language teaching and culture teaching}

Four out of nine studies have investigated teachers' teaching objectives of language teaching and culture teaching (e.g. Castro et al., 2004; Sercu et al., 2005; Atay et al., 2009; Han, 2014). The findings of their studies vary among each other or even in each study, but few scholars show strong evidence to indicate the reasons for the inconsistencies of their findings.

As for the objectives of language teaching, Spanish teachers in Castro et al. (2004), teachers from Spain, Poland, Sweden, and Belgium in Sercu et al.(2005), Turkish teachers in Atay et al.(2009), and Chinese teachers in a (2014)all regard linguistic competence and proficiency as the premier objectives of language teaching. Castro et al. (2004) have explained the findings in their research that it can be linked to teachers' belief of students' low motivation to learn the foreign language and teachers' concern with promoting students' acquisition of proficiency to use the foreign language for practical purposes. Differently, teachers from Bulgaria and Greece in Sercu et al.(2005) are more culturally orientated and Mexican teachers in Sercu et al.(2005) appear to attach greater importance to the acquisition of general learning skills.

Regarding the objectives of culture teaching, teachers from Spain, Poland, Sweden in Sercu et al.(2005) and Turkish teachers in Atay et al.(2009)define culture teaching above all in terms of providing information about daily life and routines. Atay et al.(2009)explain that it may be the result of Turkish teachers associating cultural information with communication. Turkish Teachers in Atay et al.(2009) and Chinese teachers in Han(2014)expressed strong support to help students understand their own cultures better. Atay et al.(2009) explain that it may because the teachers were not familiar enough with target language cultures, did not have much contact with English speaking people, and did not feel fully knowledgeable about the target culture so that they felt more comfortable focusing on the students' and their own native culture. Teachers from Sweden, Bulgaria, and Greece in Sercu et al.(2005)attach the greatest importance to developing attitudes of openness and tolerance towards other peoples and cultures. And Mexican teachers in Sercu et al.(2005) perceive the objectives of culture teaching in terms of the promotion of reflection on cultural differences. Differently, Spanish-language teachers in Castro et al. (2004)give priority to the teaching of aspects related to the civilization of the country, more enhancing familiarity with what is a foreign, and less promoting reflection on one's own culture and identity or intercultural relationships or the development of attitudes of openness and a positive disposition towards the unfamiliar.

\subsection{Language teachers' distribution of teaching time}

Four out of nine studies have investigated how language teachers distributed their teaching time (e.g. Castro et al., 2004; Sercu et al., 2005; Chen, 2013; Oranje \& Smith, 2018). The findings are strikingly similar that the large majority of teachers in all participating countries among the research devote less time to culture teaching than language teaching. Meanwhile, they show a clear willingness to devote more teaching time to 
IRA-International Journal of Education $\Xi^{0}$ Multidisciplinary Studies

culture teaching but they state that they experience constraints for not getting round to culture teaching more often. Castro et al. (2004) and Sercu et al. (2005) provide four common reasons to explain this phenomenon. Firstly, the Curriculum is more linguistically oriented. Secondly, there are not enough teaching periods for covering both language and culture. Thirdly, the textbooks fail to include enough cultural information. Fourthly, teachers are not well-prepared for culture teaching. And Sercu et al. (2005) add another reason that students prefer language teaching to culture teaching.

Oranje \& Smith (2018) make a comparison between the findings of themselves with those of Sercu et al. (2005) find that the phenomenon of devoting more time to language teaching than culture teaching has slightly changed with more attention has been given to culture teaching. Oranje \& Smith (2018) reckoned that the difference between New Zealand's results and Sercu et al.'s (2005) may be due to the passing 13 years, during which ILT theory has been subjected to more research, and become more recognized and widespread. Moreover, with the development of Newton et al.'s (2010) six principles of ILT to guide the development of language programs, teachers in New Zealand have certainly been at something of an advantage.

\subsection{The content and the way of language teachers culture teaching}

It has been stated above that teachers spend very little time on culture teaching, but there is still a small amount of time spent on culture teaching. Four out of nine studies (e.g. Sercu et al., 2005; Atay et al., 2009; Han, 2014; Oranje \& Smith, 2018) are very curious about the content and way of teachers' culture teaching, so they have investigated language teachers' culture teaching practices.

As for the culture teaching content, Sercu et al. (2005) and Han (2014) both find that teachers prefer the cultural information involved in teaching materials, which was consistent with the finds of other scholars (Me'ndez Garc1'a, 2003; Sercu, 2000a). Han (2014) also suggests that teachers like choosing knowledge that is familiar to them as teaching content. Similarly, Oranje \& Smith (2018) show that teachers are familiar with the overt culture (or 'High Culture', e.g. history and the Arts), and their teaching activities more related to overt culture but less related to covert culture (or 'everyday culture', e.g. gender roles and ethnic relations).

As for the way of culture teaching, Sercu et al. (2005) find that teachers most frequently employ teacher-centered activities. The authors explain that social-constructivist approaches to teaching and learning and learner autonomy approaches had just been introduced on a larger scale in many European schools, as a result of which schools were still struggling to find a balance between teacher-centered approaches and more pupil-centered autonomy fostering approaches to learning at that time. Atay et al. (2009) explain teachers seldom integrate culture-related practices into language teaching due to two reasons: one is that teachers do not know how to integrate culture teaching into language teaching and the other is that teachers lack necessary resources such as computers, the Internet, DVD players, or tape-recorders. Oranje \& Smith (2018) indicate that teachers will sacrifice culture teaching at times of pressure and teachers seldom ask students to reflect on their own culture.

\subsection{Language teachers' belief on ICC and ILT}

Four out of nine studies [e.g. Cheng (2012), Chen (2013), Han (2014), and Czura (2016)] have investigated teachers' beliefs on ICC. Their findings show that almost all participating teachers fail to clearly articulate the definition of ICC or the components of ICC. Cheng (2012) explains that ICC is considered 
IRA-International Journal of Education $\Xi^{\circ}$ Multidisciplinary Studies

relatively unimportant in most EFL (English as a foreign language) or ESL (English as a second language) teacher education (Kurogi, 1998). Most language teachers are not yet well prepared to incorporate the content of ICC into their pedagogical practices as indicated by Paige et al. (1999), Sercu (2005), Yuen and Grossman (2009), and Larzen-Osternmark (2009). Czura (2016) explains as well that teacher education programs offer insufficient guidelines on both theoretical and practical aspects of developing ICC. In addition, Czura (2016) finds that the study field of pre-teachers may affect their understanding of the concept of ICC. Pre-service teachers with typical philological education emphasize communicative, attitudinal, and social aspects of ICC, whereas student teachers majoring in history tend to place more focus on knowledge-related objectives.

Five out of nine studies have investigated teachers' beliefs on ILT (e.g. Castro et al., 2004; Chen, 2013; Han, 2014; Czura, 2016; Oranje \& Smith, 2018). They all show that teachers have realized the importance of ILT, but there is still a far distance between the actual teaching situation and the ideal ILT. Even though Castro et al.(2004) find certain parallelism between teachers' beliefs and the prescriptions found in the curriculum, many factors are hindering the way of ILT. Chen (2013) suggests that teachers worry that intercultural teaching will increase the burden of students and themselves, and teachers also don't know how to develop intercultural language teaching (Zhang, 2012). Han (2014) shows that teachers believe that their pupils should have acquired a sufficiently high level of proficiency in the foreign language before one can start to do anything in the area of ICC. And Oranje \& Smith (2018) explain it is because those teachers are left to their own devices: left to interpret ambiguity across curriculum documents and left to pursue professional development and affiliations to address training shortfalls, and teachers' exposure to ILT has not been sufficient to allow them to reconcile their culture teaching beliefs and practices, or incorporate ILT into their teaching stance.

Sercu et al. (2005), Castro et al. (2004), Cheng (2012) have investigated teachers degree of willingness to promote students' acquisition of ICC in foreign language teaching, but only Sercu et al. (2005) has investigated the factors that may affect teachers' willingness to teach intercultural competence. Teachers in Castro et al. (2004) show that they are willing to teach ICC in their classroom, while teachers in Cheng (2012) indicate negative attitudes towards ILT. But teachers in Sercu et al. (2005) fail to achieve an agreement for some of them support ILT while others do not. The authors suggest that 'the extent to which teachers believe their pupils are knowledgeable about the foreign culture'; 'the frequency of teachers' contacts with the foreign culture'; 'the percentage of immigrants in the teacher's school'; 'the reasons teachers mention for organizing school trips or exchange project'; and 'how teachers define the objectives of foreign language education and culture teaching in foreign language education' are not found to affect teachers' willingness to teach intercultural competence.

\subsection{Teachers' perceived students' attitudes towards ILT}

Sercu et al. (2005), Cheng (2012), and Kissau et al. (2014) have investigated teachers' perceived students' attitudes towards ILT according to participating teachers' self-reported belief, while Chen (2013) have investigated students' attitudes directly choosing students as respondents.

Sercu et al. (2005) find out a reasonably clear relationship appears to exist between the different dimensions of pupils' culture-and-language learning profile. Countries, comparatively with higher motivation to learn the foreign language, show more positive attitudes towards the people associated with the 
IRA-International Journal of Education छ Multidisciplinary Studies

foreign language, know more about the culture of the foreign language and feel a lower degree of difficulty in learning the foreign language, and vice versa. Differently, , Chen (2013) find that the more interested students are in cultural learning, the less effective teaching is, which explained by the author that: first, there are few cultural information in the textbooks, and teachers' knowledge reserve on culture is insufficient, so the teaching contents cannot meet the needs of students' interest in cultural learning; Second, the teacher's teaching style is not suitable for students' interests, resulting in a negative effect.

Sercu et al. (2005) and Cheng (2012) both agree that students are generally more familiar with American culture than any other culture of English-speaking countries because of the influence of textbooks, teachers, media, the Internet, and society in general. Cheng (2012) finds that students enjoyed cultural related topics and the German methodology instructor in Kissau et al. (2014) commented, 'Students who have done a study abroad program are thrilled to integrate culture into their teaching'. Another opinion was provided by a professor from the USA in Kissau et al. (2014), who stated that culture could be used as a motivational tool for students to learn a second language.

\subsection{The degree of teachers' familiarity with a foreign culture}

Sercu et al. (2005), Atay et al. (2009), and Chen (2013) have investigated the degree of teachers' familiarity with a foreign culture and the way of exposure to a foreign culture. Atay et al. (2009), and Chen (2013) show that teachers are not familiar enough with target language cultures, did not have much contact with English speaking people, and did not feel fully knowledgeable about the target culture, so that they felt more comfortable focusing on the students' and their own native culture. Sercu et al. (2005) show that the topics with which teachers appear to be most familiar are those traditionally dealt with in foreign language textbooks, namely daily life and routines; history and geography; and folklore and the media are an important source of information.

\section{Discussion and Conclusion}

Research questions mentioned above were common issues that at least four studies have noticed and some of them even tried to give reasonable explanations. Other research questions have been investigated, for example, Sercu et al. (2005) has investigated how teachers perceive the cultural dimension of teaching materials, and Cheng (2012) analyzed participants teaching materials. They all find that teachers perceive textbooks as not enormously helpful in approaching the cultural dimension of teaching, but teachers massively use them in their classrooms. The textbook of each country, each region, and even each school is different and textbooks play an important role in language teachers' cultural teaching, as a result of which textbook analysis and teachers' understanding of the textbook can be considered as a direction for future studies.

Of the studies reviewed above, $88.9 \%$ were conducted on teachers (see Appendix A), while merely $11.1 \%$ were conducted on students. Now that ILT is different from teacher-centered teaching methods, for it addresses the importance of 'learner autonomy' (Sercu et al., 2005: 83), to carry out ILT is essential to understand students' learning motivation, their attitudes towards ILT, as well as the problems they meet during ILT, and so on. Therefore, future research should include students as respondents as much as possible. 
IRA-International Journal of Education $\Xi^{\circ}$ Multidisciplinary Studies

All of the studies reviewed above, adopt research methods such as questionnaires or interviews (see Appendix A), the finding of which is based on participants' self-stated belief rather than real practices. Some studies indicated only limited correspondences between belief and practices (Feryok, 2004; Mitchell, 2005), and thus classroom observation is advised. However, as Cheng (2012) indicates that because classroom observation is difficult to conduct, self-reported practices are often the only available descriptions of educators' perceptions in the classroom. Yet, classroom observation is suitable for the case study.

According to the findings of the reviewed studies, it is found that there are many factors hindering the development of ILT, mainly including five aspects: 1) Curriculum standards have not set specific guidelines for ILT, namely, teaching contents, teaching objective, as well as contents, procedures, standards and evaluation system for the test are not formulated explicitly in terms of ILT;2) Teaching materials cannot meet the needs of ILT; 3) Teaching time for language teaching is insufficient;4) Training system of ILT for pre and in-service teachers have not well established;5) Students'motivation for ILT is not as high as expected. However, these factors were only inferred from the discussion given in each research, which has not been confirmed yet. Therefore, subsequent studies can further study the factors that affect teachers' intercultural teaching.

As the participants of each study come from different countries (the syllabus of each country, each region, and even each school are different) and different school levels, the teaching experience, and oversea experiences of each participant vary and the research method of each study is not consistent, so the inconsistencies of their findings may be due to these factors.

However, the present review has been subject to the following limitations: the data set was small and some studies may have been missed due to limitations in the search methods or selection criteria. Furthermore, the analyses and discussions of findings in the reviewed research were considerably more complex and detailed than could be reported in the review. Finally, 'culture teaching' and 'language teaching' have been used in this review for the seek of distinction, which exists ambiguity because that their integration is absolute. However, they are written in the same form in other studies, so it was retained here.

\section{Appendix A.}

\begin{tabular}{llll}
\hline Study & Year & Participants & Methods \\
\hline Castro et al. & 2004 & (35)Spanish: secondary education & questionnaires \\
Sercu et al. & 2005 & $(424)$ Belgium, Bulgaria, Poland, Mexico, Greece, & questionnaires \\
& & Spain, and Sweden: secondary education & questionnaires \\
Atay et al. & $(503)$ Turkish: primary, secondary, tertiary education & \\
& & &
\end{tabular}


IRA-International Journal of Education $\Xi^{\circ}$ Multidisciplinary Studies

\begin{tabular}{llll}
\hline Chen & 2013 & China: (36) tertiary education, (274) undergraduates & $\begin{array}{l}\text { questionnaires } \\
\text { \& interviews }\end{array}$ \\
Han & 2014 & $(1081)$ China: tertiary education & questionnaires
\end{tabular}

Kissau\&

the United States: primary, secondary education( 136 ),

questionnaires

Rodgers\&Haudeck

( 1 ) L2 methodology instructors; German: teacher

candidates ( 118 ), ( 1 ) L2 methodology instructors

Czura

2016

( 162 ) Wrocław: student teachers

questionnaires

Oranje\& Smith

2018

( 76 ) New Zealand: secondary education

questionnaires

\section{References}

[1]. Aleksandrowicz-Pędich, L., Draghicescu, J., Issaiass, D., \&Sabec, N. (2003).The views of teachers of English and French on intercultural communicative competence in language teaching. Incorporating intercultural communicative competence in language teacher education, 7-37.

[2]. Bektaş-Çetinkaya, Y. (2014). Extension of teacher knowledge: Developing the intercultural competence of pre-service foreign language teachers in Turkey. Novitas-ROYAL (Research on Youth and Language), 8(2), $153-168$.

[3]. Borg, M. (2001). Teachers' Beliefs. ELT Journal, 55(2), 186-87.

[4]. Byram, M. (1997). Teaching and assessing intercultural communicative competence. Clevedon: Multilingual Matters.

[5]. Byram, M., \& Zarate, G. (eds.) (1997). The sociocultural and intercultural dimension of language learning and teaching. Strasbourg: Council of Europe.

[6]. Czura, A. (2016). Major field of study and student teachers' views on intercultural communicative competence. Language and Intercultural Communication, 16(1), 83-98.

[7]. Cheng, C. M. (2012). The Influence of College EFL Teachers' Understandings of Intercultural Competence on Their Self-Reported Pedagogical Practices in Taiwan. English Teaching: Practice and Critique, 11(1), 164-182.

[8]. Chen, G. Q. (2013). An empirical study of college English intercultural teaching: Problems and countermeasures-Based on a case study of Heilongjiang university of science and technology. Shanghai International Studies University, Shanghai.

[9]. Castro, P., Sercu, L. \& Garcia, M. C. M. (2004). Integrating language-and-culture teaching: an investigation of Spanish teachers' perceptions of the objectives of foreign language education. Intercultural Education, 15(1), 91-104. 
IRA-International Journal of Education $\Xi^{\circ}$ Multidisciplinary Studies

[10]. Conway, C., Richards, H., Harvey, S., \& Roskvist, A. (2010).Teacher provision of opportunities for learners to develop language knowledge and cultural knowledge.Asia Pacific Journal of Education, 30, 449-462.

[11]. Derin, A. T. A. Y., Gökçe, K. U. R. T., ÇAMLIBEL, Z., \& ERSIN, P. (2009).The Role of Intercultural Competence in Foreign Language Teaching. İnönü Üniversitesi Eğitim Fakültesi Dergisi, 10(3).

[12]. Feryok, B.,\& Anne. (2005). Personal practical theories: exploring the role of language teacher experiences and beliefs in the integration of theory and practice. (Doctoral dissertation, Elsevier B.V.).

[13]. Han, X. (2014). Current situation and thinking on the cultivation of intercultural communication ability of college students -- a study on English teachers in colleges and universities. Journal of Foreign Languages, 178(3): 106-110.

[14]. Kissau, S., Rodgers, M., \& Haudeck, H. . (2014). Foreign language teaching: an international comparison of teacher beliefs. Research in Comparative \& International Education,9(2), 227.

[15]. Kurogi, A. (1998). Culture teaching in Japanese language education: A descriptive study. Unpublished doctoral dissertation, Portland State University.

[16]. Larzen-Osternmark, E. (2009).Language teacher education in Finland and the cultural dimension of foreign language teaching - a student-teacher perspective.European Journal of Teacher Education, 32, 401-21.

[17]. Méndez Garci'a, M.C. (2003) La Cultura Extranjera en los Libros de Ingle’sde Bachillerato. Jae'n: Servicio de Publicaciones de la Universidad de Jaén.

[18]. Mitchell, E.W. (2005). The influence of beliefs on the teaching practices of high school foreign language teachers. PhD thesis. University of Massachusetts, Amherst.

[19]. Newton, J., Yates, E., Shearn, S., \& Nowitzki, W. (2010). Intercultural communicative language teaching: Implications for effective teaching and learning. Wellington: Ministry of Education.

[20]. Oranje J.,\&Smith, L.F. (2018). Language teacher cognitions and intercultural Language teaching: The New Zealand perspective[J]. Language teaching Research, 33(5): 310-329.

[21]. Paige, R. M., Jorstad, H., Siaya, L., Klein, F., \& Colby, J. (1999). Culture learning in language education: A review of the research literature. In R. M. Paige, D.L. Lange, \& Y. A. Yershova. (Eds.), Culture as the core: Integrating culture into the language curriculum (pp. 47-115). Minneapolis, MN: University of Minnesota, Centre for Advanced Research in Language Acquisition.

[22]. Sercu, L. (2000a) Acquiring Intercultural Communicative Competence from Textbooks.The Case of Flemish Adolescents Learning German. Leuven: Leuven University Press.

[23]. Sercu, L. (2005). Teaching foreign languages in an intercultural world. In m. Byram\& a. Phipps (Eds.), foreign language teachers, and intercultural competence. Buffalo, NY: Multilingual Matters, Ltd.

[24]. Young, T. J., \& Sachdev, I. (2011). Intercultural communicative competence: Exploring English language teachers' beliefs and practices. Language Awareness, 20, 81-98.

[25]. Yuen, C. Y. M., \& Grossman, D. (2009). The intercultural sensitivity of student teachers in three cities. Compare, 39, 349-65.

[26]. Zhang, H. (2007). Intercultural Approach to Foreign Language Teaching. Shanghai: Shanghai Foreign Language Education Press.

[27]. Zhang, H. (2012). Intercultural education-oriented foreign language teaching: History, status and future. Foreign Language World. 149(2):2-7. 